\title{
DEVELOPMENT OF MEDICAL SCHOOL STUDENTS' ATTITUDES TOWARDS ONLINE LEARNING SCALE AND ITS RELATIONSHIP WITH E-LEARNING STYLES
}

\author{
Mustafa Onur YURDAL \\ ORCID: 0000-0002-9632-7192 \\ Faculty of Medicine, Canakkale Onsekiz Mart University \\ Canakkale, TURKEY \\ Dr. Erkan Melih SAHIN \\ ORCID: 0000-0003-1520-8464 \\ Canakkale Onsekiz Mart University Faculty of Medicine \\ Department of Family Medicine \\ Canakkale, TURKEY \\ Dr. Aysen Melek AYTUG KOSAN \\ ORCID:0000-0001-5298-2032 \\ Faculty of Medicine, Canakkale Onsekiz Mart University \\ Canakkale, TURKEY \\ Dr. Cetin TORAMAN \\ ORCID: 0000-0001-5319-0731 \\ Faculty of Medicine, Canakkale Onsekiz Mart University \\ Canakkale, TURKEY
}

Received: 16/08/2020 Accepted: 11/12/2020

\begin{abstract}
This study aims at determining students' attitudes towards distance education/online learning through a scale developed by the authors and determine the relationship between these attitudes and e-learning styles. The study carried out on students of Canakkale Onsekiz Mart University Faculty of Medicine using the online system of the university., the sample group consists 815 students from different classes, the participation rate was $89.46 \%$. Following the explanatory factor and confirmatory factor analysis resulting structure of the scale was confirmed. Construct validity, criterion validity and internal consistency of the scale were high. Multivariate regression analysis was conducted to assess the predictive strength of the students' learning styles which were determined using the e-Learning Styles Scale for Electronic Environments for the attitudes towards online learning. Presented Medical School Students' Attitudes Towards Online Learning Scale was valid and reliable instrument to measure medical school students' attitudes towards distance/online learning. Although students' attitudes toward online/distant education were divided, it was negative on the average. The regression modeling showed that the learning styles are significant predictors for attitudes towards online education and the audio-visual learning style was determined as has the highest predictive strength for attitudes towards online education. The developed tool can be used to monitor medical school students' attitudes towards distance/online learning and will contribute to preparing medical education for a change towards distance learning.
\end{abstract}

Keywords: Faculty of Medicine, online learning, e-learning style, attitude. 


\section{INTRODUCTION}

The transformation from order to disorder is a law of nature and called entropy in physics. Successful systems must constantly develop and innovate to keep their mechanism alive and respond to the requirements of the era. Ozdemir (2003) stated that to keep up with the times, the changes in the education system should be taken into account regarding the educational models used in medical education. Even if there are no continuous improvement, innovation awareness, and change within the system, non-system factors can be a driving force. The COVID-19 pandemic, which affected the entire world in 2020 and also Turkey as of March, has played such a role. Educators at every level and discipline had to adapt to the pandemic conditions and act accordingly.

The term "Distance" has been used to refer to a form of education in which learners and teachers and resources do not coexist, share the same time or place since the first day it started with the letter. The journey of distance education that started with letters and online learning that started with the internet has entered a new era with the Covid-19 pandemic, which is effective worldwide and all face-to-face education activities have been transformed into distance education and mostly online learning due to the closure of schools / universities in order to fight against the epidemic. However, distance education is "a complex process that requires careful planning, design and setting goals to create an effective learning ecology" (Bozkurt \& Sharma, 2020).

At such a critical time, there has been a big change in how teaching and learning takes place and learners physically move out of school, separating the teacher and the co-learner. Education practices during the Covid-19 pandemic are expressed in different terms in different countries (for example, distance education, e-learning, online education, homeschooling, etc.). However, these terms do not fully cover those applied during interruption of education; instead it may be better to describe these applications as Emergency Remote Education. Considering that the terms used in different countries are different, these terms are derivatives of distance education as a general term. The notable difference between emergency distance learning and distance learning is that the first is an obligation and the second is an option. With such an understanding, it is very important to approach because mistakes in definitions drive us to make mistakes in practice. For example, distance education is a planned activity, and its application is based on theoretical and practical knowledge specific to the field and field. Emergency distance education, on the other hand, is about keeping education alive with all the offline and online resources available in times of crisis (Bozkurt et al., 2020)

It can be argued that the vast majority of educators who retreat to their homes with the pandemic do not have sufficient knowledge, experience and time in distance education, and in most cases, lack of infrastructure, equipment, hardware and software, therefore, distance education studies carried out under these conditions cannot be considered exactly distance education. In addition, it is important to create a learning process that "supports different types of interaction" in order to ensure both cognitive and social participation of individuals living in separate spaces in distance education (Hodges et al., 2020)

However, it can be said that the process is not a complete distance education process in this respect, both due to the social effects of the process and the lack of experience and time to effectively design an interactive design in online courses. Hodges et al. (2020), and distance education, instructional technology etc. researchers working on the fields propose to name this period as "emergency distance education" in order to distinguish it from distance education carried out under ordinary conditions. The emphasis on the concept of "teaching" instead of education stems from the fact that this urgent process is carried out under the responsibility of the trainers (Hodges et al., 2020).

Regardless of how its name is accepted at the end of the day, this process seems to pass as an exceptional period in the history of education in general and in the history of education technology and distance education in particular (Yildirim, 2020).

During the last twenty years, digital learning technologies have become widespread in almost all learning fields including health/medical education. Although digital learning technologies and accompanying innovations have been used in medical education frequently in medical education, online learning strategies for medical education is a new research topic (Ruiz, Mintzer, \& Leipzig, 2006; Cook et al., 2008). Technologic developments have been forced medical schools to integrate new education models supported 
by technological tools as an alternative to traditional education. These alternative education models provide students an active learning environment by allowing students more interaction with the materials (a medical device, simulated patient, or medical equipment, etc.). These education models allow students to focus more on clinical problems and aims at understanding disease mechanisms by self-directed learning and deep learning through active participation (Fieschi et al., 2002).

Although some efforts made to improve medical education by alternative learning models, the actual method employed is face-to-face learning. Several medical schools made efforts to improve the effectiveness of the education program and provide students with clinical reasoning skills through some practices such as problem-based learning activities, simulated patient cases, and evidence-based medical practices. Some medical schools carried out problem-based learning activities on digital platforms due to lack of place, time, and guiders such as human resources (Mistry et al., 2019). Some medical schools across the globe conduct anatomy, histology, and evidence-based medicine practices through distance education methods (Kazoka, $\&$ Pilmane, 2019). Not only educators and educational institutions but also students should be ready for these changes in the education system. The COVID-19 pandemic is affecting the world and also Turkey and therefore, forced especially medical schools to implement distance learning methods. The success of the change in the educational processes depends not only on the accuracy and convenience of the educational models implemented but also on understanding the learner characteristics of the medical school students. Accordingly, an accurate determination of the student profiles and learner characteristics is important for medical education and also other professional training fields (Ozdemir, 2003).

On the other hand, changes in the learning environments highlight the issue of student participation. Finn and Zimmer (2012) described students' participation in the learning environment through social, cognitive, emotional, and academic elements. Social participation includes monitoring the behaviors in a learning environment; cognitive participation includes the use of cognitive resources in complex operations; emotional participation refers to the level of emotional participation in the learning activities; and finally, academic participation refers to the observable behaviors, namely, outcomes that are directly related to the learning (Cirigliano, Guthrie, \& Pusic, 2020). It is believed that more participating students are more successful compared to those with lower ones. In recent studies, direct indicators of academic participation were identified including the student's attention, completion of the given activities, the time needed for the tasks, and academic participation outside the classroom (Cirigliano, Guthrie, \& Pusic, 2020).

Several studies pointed out the importance of students' participation in distance learning methods and therefore, students' participation should be encouraged (Bagriacik Yilmaz, \& Banyard, 2020). In medical schools, especially in the first three years in which the basic sciences are taught, students participation is very low. However, distance learning may improve students' participation. Schools including distinctive education procedures such as medical schools increase the value of the efforts to promote distance learning and students' participation becomes more important. In a scale development study conducted in Turkey to measure students' attitudes towards problem-based learning, a sub-scale was developed to measure students' attitudes towards problem-based learning environments on digital platforms (Kemahli, \& Alper, 2006).

In a study (Kyaw et al., 2019), which included 12 studies conducted on 2101 medical students and conducted on the effectiveness of digital communication skills training, online modules were also used and they obtained evidence that digital education is as effective as traditional face-to-face training. However, in this study, clear information about students' satisfaction with this education system and their attitudes could not be obtained.

Vogelsang et al. (2018) stated in the study they conducted in Medical Faculties providing education in German that the expectations of Generation $\mathrm{Z}$ towards learning were different and that the expectations of Medical Education students should be investigated.

Since there are no scales measuring students' attitudes on providing all stages of the medical education through distance learning methods and since the COVID-19 pandemic made it necessary to provide medical education through online learning techniques, the authors believe that such a study could provide a strong contribution to its field of research. Accordingly, this study aims at determining medical school students' attitudes towards distance learning/online education and to determine the relationship between these attitudes and e-learning styles. 


\section{METHOD}

The study is a quantitative correlational study (Creswell, 2012; Fraenkel, Wallen, \& Hyun, 2012). This paper aims at determining medical school students' attitudes towards distance learning/online education and examining its relationship with e-learning styles.

\section{The Sample}

This study conducted at Canakkale Onsekiz Mart University Faculty of Medicine with the permission numbered KAEK-27/2020-2000058519 obtained from Canakkale Onsekiz Mart University Clinical Trials Ethics Committee. The data were collected during the COVID-19 pandemic. In this period, formal education in Turkey was suspended starting 16 March 2020, and since all educational activities of the universities were provided through the online education, the Ethics Committee allowed research on the condition using only online data collection tools. Therefore, the data was obtained simultaneously through online system of the university. A consent form was displayed when the students log in to the system of the university. The scales were presented to the students who agreed to participate in the research voluntarily. Accordingly, a total of 815 medical school students from different grades (from 1 to 6) were responded to the questionnaires and the data were collected accordingly. At that period, the medical school had a total of 911 students and the participation rate in the research was calculated as $89.46 \%$. Therefore, the research sample became a purposeful sample since the data could not be obtained from the whole population (Christensen, Johnson, \& Turner, 2014).

Since the collected data will be used for exploratory and confirmatory factor analysis as a part of the scale development and also for the examination of the relationship between students' attitudes towards online learning and students' e-learning styles, the dataset was split randomly into two groups. The exploratory factor analysis (EFA) file included data of 394 students and the confirmatory factor analysis (CFA) file for the examination of the relationship included data of 421 students. Based on the suggestions provided in the literature regarding the sample size for a scale development study (Arrindell, \& van der Ende, 1985), the authors paid attention to ensure the data size in the EFA file was about 10 times of the number of items in the instrument. Some information regarding the participants of both groups is given in Table 1.

Table 1. Demographic characteristics of the sample

\begin{tabular}{lccccc}
\hline \multirow{2}{*}{ Variable } & & \multicolumn{2}{c}{ EFA group } & \multicolumn{2}{c}{$\begin{array}{c}\text { CF and relationship analyze } \\
\text { group }\end{array}$} \\
\cline { 3 - 6 } Gender & & $\mathrm{f}$ & $\%$ & $\mathrm{f}$ & $\%$ \\
& female & 201 & 51 & 211 & 50 \\
& male & 193 & 49 & 210 & 50 \\
\hline \multirow{2}{*}{ Grade } & grade 1 & 70 & 17.8 & 103 & 24.5 \\
& grade 2 & 63 & 16 & 106 & 25.2 \\
& grade 3 & 79 & 20.1 & 48 & 11.4 \\
& grade 4 & 75 & 19 & 35 & 8.3 \\
\hline total & grade 5 & 52 & 13.2 & 42 & 10 \\
\hline
\end{tabular}

\section{Data Collection Tools}

\section{Medical School Students'Attitudes towards Distance Education/Online Learning Scale (MATDLS)}

Medical School Students' Attitudes Towards Distance Education/Online Learning Scale was developed by authors. The target group of the MATDLS is medical school students. The scale was structured as a Likert type including 40 items through a literature survey and expert opinions. Ten items of the scale were reverse coded since they reflect negative emotions and thoughts towards online learning. 
Some scholars recommended conducting EFA using principal axis factoring (PAF) for a scale development study with a non-specific theoretical framework (Warner, 2008). The EFA analyze revealed that the items 4, $11,13,14,15,16,17,18,19,24,29,30,32,33,34,35,36$, and 37 did not provide the item correlation value (0.300 and above) suggested by scholars (Büyukoztürk, 2013). Therefore, these items were excluded from the scale. The KMO value of the EFA was 0.967 , and Bartlett's Test of Sphericity was calculated as $10045.068(\mathrm{sd}=253, \mathrm{p}<0.05)$. The calculated values were higher than those suggested in the previous studies (Cokluk, Sekercioglu, \& Buyukozturk, 2010; Field, 2018; Tabachnick, \& Fidell, 2013). A varimax axis rotation was performed to clearly define the items of the sub-scales (Ozdamar, 2013). Following the rotation, remaining items were grouped under two sub-scales: a) Attitudes Towards Online Learning (ATOL) and b) Attitudes Towards Online Medical Education (ATOME). The sub-scales and the items are presented in Table 2.

Table 2. The sub-scales determined using the "Varimax" axis rotation and the items included in these subscales

\begin{tabular}{|c|c|c|c|}
\hline \multirow[t]{2}{*}{ Items } & \multicolumn{2}{|c|}{ sub-scales } & \multirow[t]{2}{*}{$\begin{array}{l}\text { name and properties of the } \\
\text { sub-scales }\end{array}$} \\
\hline & 1 & 2 & \\
\hline \multicolumn{4}{|l|}{$\begin{array}{l}\text { 21. Making classroom lessons through the online system } \\
\text { contributes to personalize my study program. }\end{array}$} \\
\hline $\begin{array}{l}\text { (Sinif derslerinin online sisteme gecirilmesi, ders calisma } \\
\text { programimi kisisellestirmeme katki saglar.) }\end{array}$ & 0.826 & & \\
\hline \multicolumn{4}{|l|}{$\begin{array}{l}\text { 26. Online education allows me to use my time more efficiently } \\
\text { compared to classroom lessons. }\end{array}$} \\
\hline $\begin{array}{c}\text { (Online egitim zamanini sinif derslerinden daha verimli kullanmami } \\
\text { saglar.) }\end{array}$ & 0.807 & & \\
\hline $\begin{array}{l}\text { 25. I adapt easily to online education. } \\
\text { (Online egitime kolayca uyum saglarim.) }\end{array}$ & 0.781 & & \\
\hline $\begin{array}{l}\text { 22. Online education contributes to the use of audio-visual } \\
\text { materials. }\end{array}$ & \multirow[t]{2}{*}{0.764} & & \\
\hline \multicolumn{3}{|l|}{ (Online egitim gorsel-isitsel ogelerin kullanimina katki yapar.) } & \\
\hline 31. Online education is very rich since it's audio-visual interactive. & \multirow{2}{*}{0.764} & & \multirow{2}{*}{$\begin{array}{l}\text { Attitudes Towards Online } \\
\text { Learning (ATOL). }\end{array}$} \\
\hline (Online egitim gorsel, isitsel, etkilesimli olarak buyuk zenginliktir.) & & & \\
\hline $\begin{array}{l}\text { 28. Online access to lecture notes about lessons/internships, makes } \\
\text { me feel free. }\end{array}$ & \multirow{3}{*}{0.762} & & Includes 11 items. \\
\hline (Dersler/stajlarla ilgili ders notlarina online erisim bana kendimi & & & No reverse coded items. \\
\hline 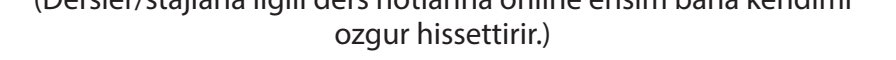 & & & The score that can be \\
\hline $\begin{array}{l}\text { 23. Online education is better than classroom education which has } \\
\text { physical limitations. }\end{array}$ & \multirow[b]{2}{*}{0.760} & & varies between 11-55. \\
\hline $\begin{array}{c}\text { (Online egitim fiziksel kisitliliklara sahip sinif egitiminden } \\
\text { ustundur.) }\end{array}$ & & & $\begin{array}{l}\text { This factor explains } 36 \% \text { of } \\
\text { the variance. }\end{array}$ \\
\hline \multicolumn{4}{|l|}{$\begin{array}{l}\text { 27. I like being informed about lecture notes through the distance } \\
\text { learning environment. }\end{array}$} \\
\hline $\begin{array}{c}\text { (Uzaktan egitim ortamindaki ders notlarindan bilgi edinmekten } \\
\text { hoslanirim.) }\end{array}$ & 0.728 & & \\
\hline \multicolumn{4}{|l|}{$\begin{array}{l}\text { 20. The classroom lessons in medical education can be provided } \\
\text { online without any loss. }\end{array}$} \\
\hline $\begin{array}{l}\text { (Tip egitimindeki sinif dersleri bir kayip olusturmadan online olarak } \\
\text { verilebilir.) }\end{array}$ & 0.711 & & \\
\hline \multicolumn{4}{|l|}{ 38. I encourage my classmates to take online education. } \\
\hline $\begin{array}{c}\text { (Sinif arkadaslarimin online egitim almalari icin onlari tesvik } \\
\text { ederim.) }\end{array}$ & \multicolumn{3}{|l|}{0.700} \\
\hline $\begin{array}{l}\text { 39. I support all efforts to extend distance education. } \\
\text { (Uzaktan egitimi yayginlastiracak her tur cabayi desteklerim.) }\end{array}$ & \multicolumn{3}{|l|}{0.692} \\
\hline
\end{tabular}


6. The attitudes that a doctor should have can be gained online.

(Bir hekimin sahip olmasi gereken tutumlar online olarak edinilebilir.)

2. The goals of medical education can be achieved using distance education methods.

(Uzaktan egitim yontemleriyle tip egitimi amacina ulasabilir.)

5. The skills that a doctor should have can be provided online.

(Hekim yetistirmek icin gerekli beceriler online olarak kazandirabilir.)

7. The communication way of a doctor with his patient and patient's relatives can be taught online.

(Hekimin, hastasi ve yakinlariyla nasil iletisim kuracagi online olarak ogretilebilir.)

9. Patient consultation can be taught online.

(Bir hastanin nasil muayene edilecegi online olarak ogretilebilir.)

12. Emergency medicine practice can be taught online.

(Acil tip uygulamalari online ogretilebilir.)

0.788

8. I can use the information that I gained through distance education (for example, measuring blood pressure) as a skill when I face with a patient.

(Zor haber verme [olum haberi verme gibi] becerisi online ogretilebilir.)

40. I enable doctor training through distance education if I'm the Health Minister.

(Saglik bakani olsam uzaktan egitimle hekim yetistirilmesini saglarim.)

1. Online access to lecture notes about lessons/internships is ideal for doctor training.

(Derslerle/stajlarla ilgili ders notlarina online erisim hekim yetistirmede idealdir.)
Attitudes Towards Online Medical Education (ATOME). Includes 11 items.

No reverse coded items.

The score that can be obtained from the scale varies between 11-55.

This factor explains $35 \%$ of the variance.

To examine the criterion validity of ATOL and ATOME sub-scales of the MATDLS, correlation analyses were conducted between the total scores of the sub-scales and student's scores on Attitude Towards e-Learning Scale and the correlation values were calculated as 0.78 and 0.72 , respectively. These results considered a high level of criterion validity.

The Cronbach's alpha coefficients were also calculated to check the internal consistency of both sub-scales. The Cronbach's alpha is calculated as 0.96 for the ATOL, and 0.92 for the ATOME, and 0.97 for the whole scale. These values indicated a high internal consistency for both sub-scales and the whole scale.

The two-factor structure obtained with the EFA was analyzed with CFA. The diagram obtained with the DFA is shown in Fig. 1. 


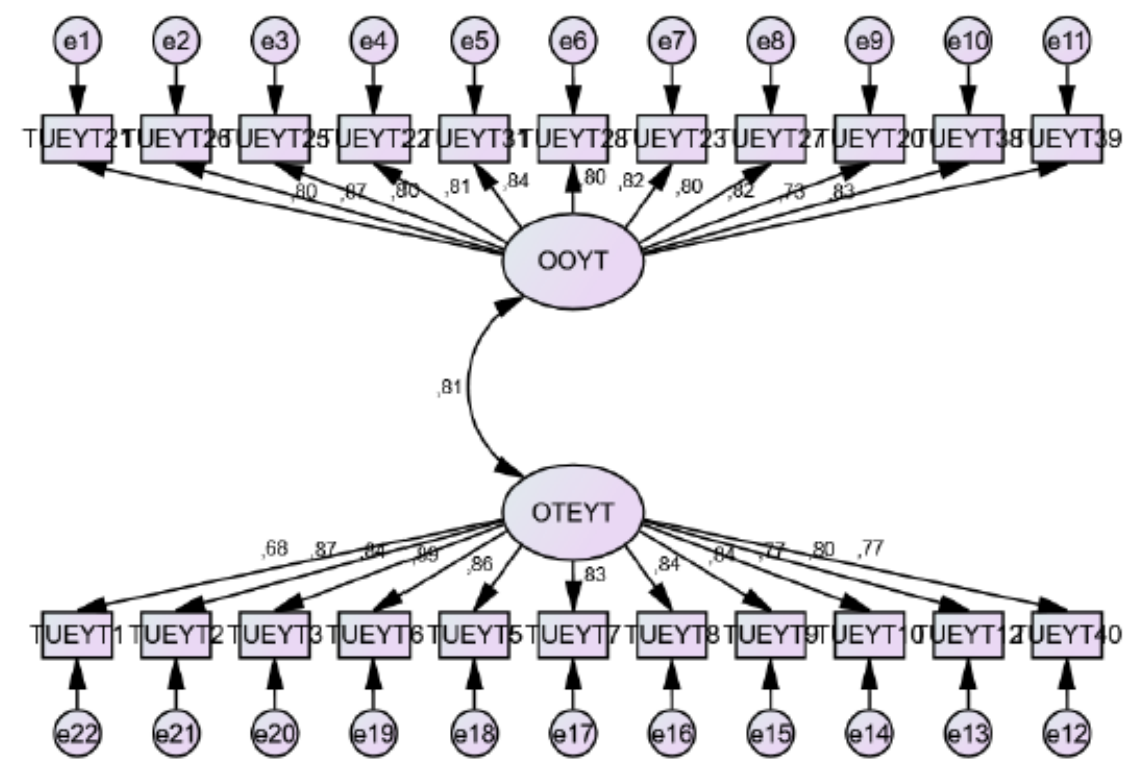

Figure 1. Path diagram (standardized values) of the confirmatory factor analysis for Medical School Students' Attitudes Towards Distance Education/Online Learning Scale (MATDLS [TUEYT in Turkish]). ATOL (OOYT in Turkish): Students' Attitudes Towards Online Learning, ATOME (OTEYT in Turkish): Students' Attitudes Towards Online Medical Education

The fit indexes of the path diagram of the CFA given in Fig. 1 were calculated as X2/sd=2.99, RMSEA=0.049, $\mathrm{RMR}=0.048, \mathrm{NFI}=0.961, \mathrm{IFI}=0.982, \mathrm{CFI}=0.970, \mathrm{AGFI}=0.927$, and $\mathrm{GFI}=0.933$. These values are the recommended values for fitting in the previous studies (Anderson, \& Gerbing, 1984; Bentler, 1990; Cokluk, Sekercioglu, \& Buyukozturk, 2010; Hooper, Coughlan, \& Mullen, 2008; Hu, \& Bentler, 1999; Kline, 2005; Marsh, Balla, \& McDonald, 1988; Ozdamar, 2013, Simsek, 2007; Tabachnick, \& Fidell, 2013, Vieira, 2011).

\section{e-Learning Styles Scale for Electronic Environments}

This scale was developed by Gulbahar and Alper (2014) to determine students' learning styles in online learning environments. The scale was developed with the students registered in the distance learning program of the university. As a result of the validity and reliability analyzes, the scale was determined as consists of seven factors including 38 items. These factors are independent learning ( 4 items), social learning ( 6 items), audio-visual learning ( 8 items), active learning ( 6 items), verbal learning ( 7 items), logical learning ( 3 items), and intuitive learning styles ( 4 items). This was a 5-point Likert type scale. The developers of the scale were calculated the fit indexes of the confirmatory factor analysis as RMSEA $=0.056, \mathrm{SRMR}=0.047$, GFI $=0.90$, AGFI $=0.88, \mathrm{CFI}=0.98, \mathrm{NNFI}=0.97$, and IFI $=0.98$. The Cronbach's alpha values for the reliability of the sub-scales were found as varied between 0.72-0.87.

\section{General Attitude Scale towards e-Learning}

This scale was developed by Haznedar and Baran (2012) to measure the general attitudes of teacher education students towards e-learning. This is a Likert type scale consists of 20 items. The scale was used as a onefactor scale when the negative items reverse coded. The reliability of the one-factor scale was calculated as 0.93. General Attitude Scale Towards e-Learning was used in the present study to determine the concurrent validity of the MATDLS scale were was developed by the authors. MATDLS and General Attitude Scale Towards e-Learning was applied to the medical school students, the correlation coefficient between the obtained data was calculated and the calculated coefficient was determined as the concurrent validity value of the MATDLS. 


\section{Analysis of Data}

Before conducting EFA, CFA, and other data analysis methods, the dataset was checked and had no missing values were found. Based on the Central Limit Theorem which argues if the sample size is large enough $(>30)$ it should represent a normal distribution, and a violation of the normality assumption will not cause a big problem (Everitt, \& Howell, 2005; Field, 2018; Pallant, 2016; Tabachnick, \& Fidell, 2013), we decided to adopt parametric statistical techniques for analysis.

\section{FINDINGS}

\section{The Relationships Between Medical School Students'Attitudes Towards Online Learning And E-Learning Styles}

Medical School Students' Attitudes Towards Distance Education/Online Learning Scale (MATDLS) and e-Learning Styles Scale for Electronic Environments were used in this study. MATDLS has two sub-factors, Attitudes Towards Online Learning (ATOL) and Attitudes Towards Online Medical Education (ATOME). E-Learning Styles Scale consists of independent learning, social learning, audio-visual learning, active learning, verbal learning, logical learning, and intuitive learning sub-factors. The descriptive statistics of the participating students' scores on these sub-factors are given in Table 3.

Table 3. Descriptive statistics of attitudes towards online learning and e-learning styles

\begin{tabular}{cccccc}
\hline Scales & $\mathrm{N}$ & Mean $(\bar{X})$ & Median & Mode & $\mathrm{S}$ \\
\hline Audio \& visual learning style & 421 & 26.51 & 27 & 24 & 7.34 \\
Verbal learning style & 421 & 20.78 & 21 & 21 & 5.82 \\
Active learning style & 421 & 18.42 & 18 & 18 & 5.22 \\
Social learning style & 421 & 18.22 & 18 & 18 & 5.33 \\
Independent learning style & 421 & 12.94 & 12 & 12 & 3.96 \\
Logical learning style & 421 & 9.98 & 9 & 9 & 3.13 \\
Intuitive learning style & 421 & 12.06 & 12 & 12 & 3.46 \\
Attitudes Towards Online Learning (ATOL) & 421 & 27.02 & 28 & 33 & 10.07 \\
Attitudes Towards Online Medical Education (ATOME) & 421 & 22.83 & 22 & 11 & 9.71 \\
\hline
\end{tabular}

The lowest score that can be obtained from the audio \& visual learning sub-factor is 8 and the highest score is 40. The arithmetic mean of the students' scores on this factor was 26.51 . The lowest score that can be obtained from the verbal learning sub-factor is 7 and the highest score is 35 . The arithmetic mean of the students' scores on this factor was 20.78. The lowest score that can be obtained from the active learning subfactor is 6 and the highest score is 30 . The arithmetic mean of the students' scores on this factor was 18.42. The lowest score that can be obtained from the social learning sub-factor is 6 and the highest score is 30 . The arithmetic mean of the students' scores on this factor was 18.22. The lowest score that can be obtained from the independent learning sub-factor is 4 and the highest score is 20 . The arithmetic mean of the students' scores on this factor was 12.94. The lowest score that can be obtained from the logical learning sub-factor is 3 and the highest score is 15 . The arithmetic mean of the students' scores on this factor was 9.98. The lowest score that can be obtained from the intuitive learning sub-factor is 4 and the highest score is 20 . The arithmetic mean of the students' scores on this factor was 12.06. The mean scores for all learning subdimensions were higher than the half of the highest score than can be obtained from the corresponding subdimension. Therefore, it can be argued that all the learning styles of the students were higher for e-learning.

The lowest score that can be obtained from the sub-factor of attitudes towards online learning is 11 and the highest score is 55. The arithmetic mean of the students' scores on this factor was 27.02. This mean score is lower than half of the highest score than can be obtained from this factor but almost equal to the half. Accordingly, it can be stated that the students' attitudes towards online learning torn between positive and negative. 
The lowest score that can be obtained from the sub-factor of attitudes towards online medical education is 11 and the highest score is 55 . The arithmetic mean of the students' scores on this factor was 22.83 . This mean score is lower than the half of the highest score than can be obtained from this factor. Therefore, it can be argued that students' attitudes towards online medical education were negative.

The predictive strength of the Medical School Students' e-Learning Styles for Students' Attitudes towards Online Learning

In the current study, the prediction of medical school students' e-learning styles for students' attitudes towards distance education/online learning was examined using multivariate regression analysis. The goodness of fit results for multivariate regression models were presented in Table 4.

Table 4. Goodness of fit for regression models

\begin{tabular}{ccccc}
\hline Variables & $\mathrm{N}$ & $\mathrm{R}^{2}$ & $\mathrm{~F}$ & $\mathrm{p}$ \\
\hline Audio \& visual learning style & 421 & 0.064 & 14.374 & 0.000 \\
Verbal learning style & 421 & 0.085 & 19.291 & 0.000 \\
Active learning style & 421 & 0.061 & 13.613 & 0.000 \\
Social learning style & 421 & 0.068 & 15.177 & 0.000 \\
Independent learning style & 421 & 0.112 & 26.224 & 0.000 \\
Logical learning style & 421 & 0.036 & 7.759 & 0.001 \\
Intuitive learning style & 421 & 0.089 & 20.373 & 0.000 \\
\hline
\end{tabular}

As seen in Table 4, the models of seven variables (Audio-visual, Verbal, Active, Social, Independent, Logical, and Intuitive learning style), which are the predictors of the output variables (ATOL and ATOME) were significant $(\mathrm{F}=14.374, \mathrm{~F}=19.291, \mathrm{~F}=13.613, \mathrm{~F}=15.177, \mathrm{~F}=26.224, \mathrm{~F}=7.759$, and $\mathrm{F}=20.373 \mathrm{p}<0.05)$. Accordingly, the obtained regression models were deemed appropriate. The maximum predictive strength was obtained for the independent learning style $\left(\mathrm{R}^{2}=0.112,11 \%\right)$ and followed by intuitive, verbal, social, audio-visual, active, and logical learning styles, respectively. The predictions regarding the regression models are shown in Table 5.

Table 5. The predictive strength of the e-learning styles for attitudes towards distance education/online learning

\begin{tabular}{cccccc}
\hline & & $\beta$ & Standard Error & $\mathrm{t}$ & $\mathrm{p}$ \\
\hline \multirow{3}{*}{ Audio \& visual learning style } & Constant & 22.512 & 1.004 & 22.43 & 0.000 \\
& ATOL & 0.277 & 0.056 & 4.96 & 0.000 \\
& ATOME & -0.152 & 0.058 & -2.64 & 0.009 \\
& Constant & 16.218 & 0.787 & 20.60 & 0.000 \\
Verbal learning style & ATOL & 0.109 & 0.044 & 2.50 & 0.013 \\
& ATOME & 0.070 & 0.045 & 1.55 & 0.122 \\
Active learning style & Constant & 15.045 & 0.714 & 21.06 & 0.000 \\
& ATOL & 0.147 & 0.039 & 3.70 & 0.000 \\
& ATOME & -0.026 & 0.041 & -0.63 & 0.527 \\
Social learning style & Constant & 14.489 & 0.727 & 19.93 & 0.000 \\
& ATOL & 0.135 & 0.040 & 3.33 & 0.001 \\
Independent learning style & ATOME & 0.004 & 0.042 & 0.09 & 0.926 \\
& Constant & 9.689 & 0.528 & 18.36 & 0.000 \\
& ATOL & 0.174 & 0.029 & 5.94 & 0.000 \\
& ATOME & -0.064 & 0.030 & -2.10 & 0.037 \\
Logical learning style & Constant & 8.718 & 0.435 & 20.04 & 0.000 \\
& ATOL & 0.088 & 0.024 & 3.66 & 0.000 \\
& ATOME & -0.049 & 0.025 & -1.97 & 0.051 \\
Intuitive learning style & Constant & 9.299 & 0.467 & 19.93 & 0.000 \\
& ATOL & 0.103 & 0.026 & 3.97 & 0.000 \\
& ATOME & -0.001 & 0.027 & -0.03 & 0.977 \\
\hline
\end{tabular}


The constant term is significant in all predictions. Accordingly, there may some variables which may significantly predictive that not included in the regression model. Independent learning, social learning, audio-visual learning, active learning, verbal learning, logical learning, and intuitive learning styles are positive significant predictors $(\mathrm{p}<0.05)$ for attitudes towards online learning. In other words, the higher use of these learning styles, the higher the positive attitudes towards online learning. Verbal learning, active learning, social learning, logical learning, and intuitive learning styles are not positive significant predictors $(p>0.05)$ for attitudes towards online medical education. The audio-visual and independent learning styles are negative significant predictors $(\mathrm{p}<0.05)$ for attitudes towards online medical education. Therefore, the higher use of the audio-visual learning style and independent learning styles indicate higher negative attitudes towards online medical education.

\section{RESULTS, DISCUSSION AND RECOMMENDATIONS}

The study presents an instrument to measure medical school students' attitudes towards distance education/ online learning. The attitudes of students with different learning styles towards online medical education were compared and explained. Currently, there are no examples across the world regarding providing all stages of medical education through distance education methods. However, during the COVID-19 pandemic, medical schools had to provide education through distance education/online learning as in all formal and higher education. The results obtained in the current study presents an instrument to measure medical school students' attitudes towards distance education/online learning as well as examines the attitudes of the students in the sample group towards such education techniques and the effect of the learning styles on these attitudes. As an overall evaluation, students' attitudes towards online learning were determined as torn between positive and negative, on the other hand, they exhibit negative attitudes towards online medical education.

Harden initiated a practice, "International Virtual Medical School (IVIMEDS)" in 2002 which also called as the future of medical education and he stated that independent learning is one of the properties of CRISIS, the education model they conducted in this platform including continued medical education practices (Harden, 2005; Harden, \& Hart, 2002). A sub-dimension of the Attitudes Towards Distance Learning/ Online Education Scale introduced in the current study is independent learning. It was emphasized that independent learning is important for both learning processes of medical school students and sustained medical education processes that continue after graduation.

In a study carried out by Mubayrik (2020) on medical school graduates, it was found that $67 \%$ of the participants who had previously attended one of the distance education methods had positive attitudes towards distance education due to its advantages and flexibility in time. This result highlighted the importance of distance education methods on widening continued medical education to the international level.

The results of a previous study revealed that $95 \%$ of the students are motivated to online and digital medical education practices as a result of offering rich audio-visual materials or digital materials that help stimulating more senses (Kazoka, \& Pilmane, 2019). In a study carried out by Yurdal (2015), among students of the Faculty of Medicine, a positive and significant relationship was found between students' willingness to learn, self-control skills, and learning in the web environment. Although this research was conducted in the same faculty, it cannot be said that students' attitudes towards online learning are positive.

Some studies suggested that pre-graduate medical education can be standardized through distance education regardless of the clinical experiences of the students (Michaelsen, 2001). The number of students enrolling in medical schools is limited to schools' clinical practice capacity. As a result of the need for more doctors, there are many medical schools across the world with such restrictions. In Turkey, currently, 117 medical schools are active and provide education. Since medical universities are fully autonomous regarding preparing and implementing the curriculums, there are no mechanisms that compare the equivalency of medical universities' curriculums. As an easy solution to this issue, accreditations of medical curriculums are not accessed in all medical schools and there is no such obligation for this yet. Under these circumstances, providing a part of curriculums through distance education/online learning may contribute to providing equivalent curriculums among different schools. However, the suitability of online education methods for medical education, especially for clinical education is a controversial issue. To the best of our knowledge, 
there are no studies addressing medical school students' attitudes towards distance learning/online education. The present paper provides information as well as presents a valid and reliable instrument than can be used in future studies.

Providing all stages of medical education through distance education will improve the effectiveness of individualized education programs considering the e-learning styles of the students. Moreover, to improve the effectiveness of distance medical education, establishing relevant institutions such as "Center of Excellence for Online Medical Education” may be useful (Ruiz, Mintzer, \& Leipzig, 2006).

Continuous change in education procedures and methods, as well as providing medical education through distance education methods require reorganization of the curriculums considering these techniques. Therefore, considering the fact that medical schools provided educational content that prepared for faceto-face education through distance education during the pandemic, this education becomes a controversial issue.

Students combine different learning styles in themselves uniquely. On the other hand, the current curriculums are solid and do not have any flexibility for different student profiles. Many studies indicated that medical school students have different learning styles (Kalaca, 2004; Gulpinar, 2014; Salihu et al., 2020; Javaeed et al., 2020). The findings of the present study also showed the presence of a wide range of learning styles among participants. It is highly possible that distance education/online learning can be more suitable for students with different learning styles. Accordingly, the regression modeling conducted in this study revealed that learning styles are significant predictors for attitudes towards online education. It should be noted that the audio-visual learning style displayed the highest predictive power for attitudes towards online education $(\beta=0.277)$.

As suggested in several studies and taking into account the students' negative attitudes towards distance medical education, although distance education is unlikely to replace classroom education, updating of teaching philosophy, optimizing teaching, establishing flexible and diverse assessment systems can promote the reform of traditional undergraduate medical education (Zhao, Li \& Feng, 2018).

In 1999, the "United States Medical Licensing Exam" (USMLE) moved to computer-based testing, and some medical school graduates in Turkey are also entered this exam. On the other hand, Lim et al. (2006) carried out a study determining medical school students' attitudes towards computer-based testing. Students of the National University of Singapore, Yong Loo Lin School of Medicine participated in that study and results revealed that $79.8 \%$ of the students preferred computer-based exams instead of paper-based exams. However, in this study, during the development of MATDLS, the items measuring the student's attitudes towards distance assessment and evaluation systems were excluded from the scale since these items were not helpful. It can be argued that the medical school student's attitudes towards distance assessment and evaluation systems are not developed yet or students may have no opinions about distance assessment of medical students.

In a study carried out by Mirmoghtadaie et al. (2019), it was found that students who have medical education through e-learning methods had no idea whether this education method increased their academic success or not. Considering the answers of the students to the MATDLS that developed in this study, it was found that the students believe that e-learning increases their academic success.

According to the MATDLS scale, while medical school students had no positive attitudes towards gaining required skills through online learning, they also had no negative attitudes. In a study carried out by Bhatti and Bertoni (2019), it was revelated that the gaps in the learning achievements, especially outcomes related with the skills that may occur as a result of distance medical education can be bridged through an online education supported with case-based discussions, skills-based training, and short lessons.

Pre-graduate medical education curricula should be designed with an approach that can continue education in crises as in Covid-19, and students and educators should also be prepared for this, however, it is not seen that the students of the Faculty of Medicine have a positive attitude towards distance education, and they have a program design that includes more practical applications despite theoretical training in the background of medical education. 
In addition to theoretical applications, medical education programs that include many Basic Professional Skills applications in order to prevent students from depriving of many practical skills that cannot be compensated in emergency situations, case discussions including virtual reality, augmented virtual reality, artificial intelligence applications, online applications that will improve clinical skills should also be improved. The creation of such experiences may be of vital importance due to the low level of authentic patient encounter among clinical period (clerkship) students, where practical training is the majority. Such practices will also be useful for students to use review strategies and learning reinforcement during face-toface training in the post-Covid 19 normalization period. Of course, this situation can be seen as a factor that encourages learning for the student. On the other hand, an instructional design that blends online learning and face-to-face education will prepare for universal education platforms and extraordinary conditions.

In addition, online education options will be offered as a complementary education option in medical education programs, and educational system components will be prepared for education programs that include distance education methods that are likely to replace face-to-face education, whose permanence is doubtful in the future.

When it is considered for educators, as some research points out (O'Doherty et al., 2018; Rhim \& Han, 2020), in order to prevent such emergency distance education from being interrupted and to continue education, it would be appropriate to equip medical educators with skills on the use of technology in education in the pedagogical education received by medical educators.

Covid 19 period can be an opportunity to eliminate the differences between technology use skill levels between learners and educators, for whom the definition of Generation $\mathrm{Z}$ is made. Moreover, considering that healthcare professionals should be lifelong learners, it will be able to support medical students of this period in lifelong learning; it can be said that self-directed learning, independent learning skills and skills towards reaching the source of information can be improved.

\section{BIODATA and CONTACT ADDRESSES of AUTHORS}

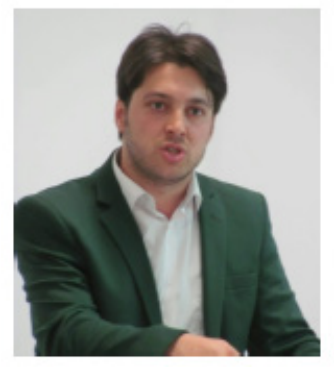

Mustafa Onur YURDAL is educational expert. He received undergraduate education in the computer and instructional technologies. He has a master's degree in curriculum \& instruction. He is currently working in at Canakkale Onsekiz Mart University, Medical School. He is fields of study are of particular interest: Research in education, curriculum $\&$ instruction, medical education.

Mustafa Onur YURDAL

Medical Education, Faculy of Medicine

Address: Canakkale Onsekiz Mart University, 17010, Canakkale, Turkey

Phone: +90 5435062785

E-mail: monuryurdal@yahoo.com

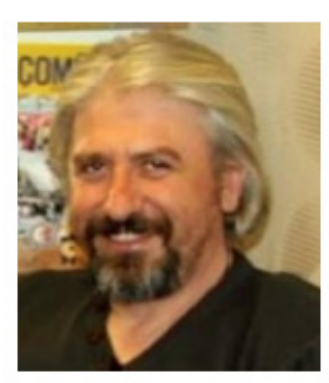

Erkan Melih SAHIN is a Professor of Family Medicine at Canakkale Onsekiz Mart University Faculty of Medicine. Dr. Erkan Melih SAHIN graduated from Hacettepe University Medical School in 1994, worked in primary care system for a year and completed his Family Medicine residency training at Ankara Numune Training and Research Hospital in 1999. He has been a faculty member at Trakya University Medical Faculty till 2008, and Canakkale Onsekiz Mart University Medical Faculty until then. He has been an associate professor in 2010 and professor in 2018. In addition to being the head of the Department of Family Medicine, he held various positions in the Department of Medical Education, served as the chief coordinator of education program of Faculty of Medicine between 2011-2018 at intervals. He was a member of Turkish Board of Family Medicine and Turkish Board of Accreditation of Medical Education. He has over than 100 journal articles published and many book chapters and conference presentations. 
Erkan Melih SAHIN

Department of Family Medicine, Canakkale Onsekiz Mart University Faculty of Medicine,

Address: Canakkale Onsekiz Mart University, 17010, Canakkale, Turkey

Phone: +90 5053026571

E-mail: emsahin@yahoo.com

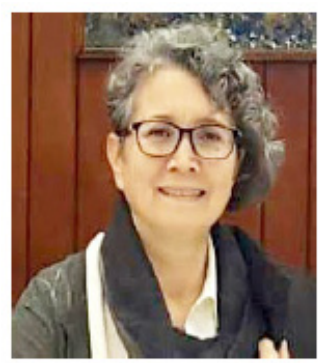

Aysen Melek AYTUG KOSAN is an educational expert. She received undergraduate education in the medical school. She has a master's degree in education assessment. She has a $\mathrm{PhD}$ in education assessment. She took part in the accreditation processes of Ankara University, Selcuk University and Canakkale Onsekiz Mart University Medical School. She is a member of the National Medical Education Accreditation Board in Turkey. She is currently working as an assistant professor in the medical education department of Canakkale Onsekiz Mart University, Medical School.

\section{Aysen Melek AYTUG KOSAN}

Medical Education, Faculy of Medicine

Address: Canakkale Onsekiz Mart University, 17010, Canakkale, Turkey

Phone: +90 5337137768

E-mail: aysenay1@yahoo.com

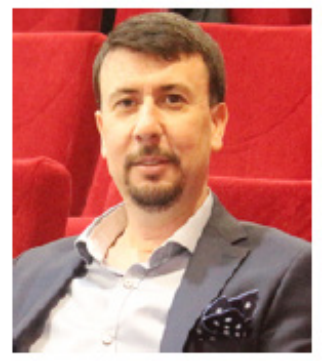

Cetin TORAMAN is an educational expert. He received undergraduate education in the field of guidance and psychological counseling. He has a master's degree in education assessment. He has a master's degree in curriculum \& instruction. He has a $\mathrm{PhD}$ in educational research methods and statistics. He has a $\mathrm{PhD}$ in curriculum $\&$ instruction. He is currently working as an assistant professor in the medical education department of Canakkale Onsekiz Mart University, Medical School. He is fields of study are of particular interest: Educational assessment, statistics, research in education, curriculum $\&$ instruction, medical education.

\section{Cetin TORAMAN}

Medical Education, Faculy of Medicine

Address: Canakkale Onsekiz Mart University, 17010, Canakkale, Turkey

Phone: +90 5359634181

E-mail: toramanacademic@gmail.com

\section{REFERENCES}

Anderson, J. C., \& Gerbing, D. W. (1984). The effect of sampling error on convergence, improper solutions, and goodness of fit indices for maximum likelihood confirmatory factor analysis. Psychometrika, 49(2), 155-173. https://doi.org/10.1007/BF02294170.

Arrindell, W. A., \& van der Ende. J. (1985). An empirical test of the utility of the observations to variables ratio in factor and components analysis. Applied Psychological Measurement, 9(2), 165-178.

Bagriacik Yilmaz, A., \& Banyard, P. (2020). Engagement in Distance Education Settings: A Trend Analysis. Turkish Online Journal of Distance Education, 21(1), 101-120.

Bentler P. M. (1990). Comparative fit indexes in structural models. Psychological Bulletin, 107(2), 238-246.

Bhatti, D., \& Bertoni, J. (2019). Feasibility of online medical education for distance learning: Experiences of mini-fellowship in movement disorders. Journal of the Neurological Sciences, 405, 123-124.

Bozkurt, A., \& Sharma, R. C. (2020). Emergency remote teaching in a time of global crisis due to Corona Virus pandemic. Asian Journal of Distance Education, 15(1), i-vi. https://doi.org/10.5281/ zenodo. 3778083 
Bozkurt, A., Jung, I., Xiao, J., Vladimirschi, V., Schuwer, R., Egorov, G., ... \& Rodes, V. (2020). A global outlook to the interruption of education due to COVID-19 Pandemic: Navigating in a time of uncertainty and crisis. Asian Journal of Distance Education, 15(1), 1-126.

Buyukozturk, S. (2013). Sosyal bilimler icin veri analizi el kitabi [Data analysis handbook for social sciences] (18th Edition). Ankara: Pegem Yayinlari.

Cattell, R. B. (1978). The scientific use of factor analysis. The USA: Plenum.

Christensen, L. B., Johnson, R. B., \& Turner, L. A. (2014). Research methods, design, and analysis. The USA, Boston: Pearson Education, Inc.

Cirigliano, M. M., Guthrie, C. D., \& Pusic, M. V. (2020). Click-level learning analytics in an online medical education learning platform. Teaching and Learning in Medicine, 1-12.

Cook DA, Levinson AJ, Garside S, Dupras DM, Erwin PJ, Montori VM. (2008). Internet-based learning in the health professions: a meta-analysis. The Journal of the American Medical Association; 300(10): $1181-1196$.

Creswell, J. W. (2012). Educational research, planning, conducting, and evaluating quantitative and qualitative research. The USA, Boston: Pearson Education, Inc.

Cokluk, O., Sekercioglu, G., \& Buyukozturk, S. (2010). Sosyal bilimler icin cok degiskenli istatistik. [Multivariate statistics for social sciences]. Ankara: Pegem Akademi.

Everitt, B. S., \& Howell, D. C. (2005). Encyclopedia of statistics in behavioral science. The UK: John Willey and Sons.

Field, A. (2018). Discovering statistics using IBM SPSS Statistics. The USA: Sage.

Fieschi, M., Soula, G., Giorgi, R., Gouvernet, J., Fieschi, D., Botti, G., Volot, F. \& Berland, Y. (2002). Experimenting with new paradigms for medical education and the emergence of a distance learning degree using the internet: teaching evidence-based medicine. Medical informatics and the internet in medicine, 27(1), 1-11.

Finn, J. D., \& Zimmer, K. S. (2012). Student engagement: What is it? Why does it matter?. In Handbook of research on student engagement (pp. 97-131). Springer, Boston, MA.

Fraenkel, J. R., Wallen, N. E. \& Hyun, H. H. (2012). How to design and evaluate research in education. USA: McGraw-Hill Companies Inc.

Gorsuch, R. L. (1974). Factor analysis. The USA: Saunders.

Gulbahar, Y., \& Alper, A. (2014). Elektronik ortamlar icin e-ogrenme stilleri olceginin gelistirilmesi [Development of e-learning styles scale for electronic environments]. Egitim ve Bilim, 39(171), 421-435.

Gulpinar, M. A. (2014) Learning Styles of Preclinical Medical Students. Hacettepe University Journal of Education, 29(3), 68-80.

Hair, J. F., Black, W. C., Babin, B. J., \& Anderson, R. E. (2014). Multivariate data analysis. The UK, Harlow: Pearson Education Limited.

Harden, R. M. \& Hart, I. R. (2002) An international virtual medical school (IVIMEDS): the future for medical education? Medical Teacher, 24:3, 261-267.

Harden, R. M. (2005). A new vision for distance learning and continuing medical education. Journal of Continuing Education in the Health Professions, 25(1), 43-51.

Haznedar, O., \& Baran, B. (2012). Egitim fakultesi ogrencileri icin e-ogrenmeye yonelik genel bir tutum olcegi gelistirme calismasi [Development of a general attitude scale towards e-learning for faculty of education students]. Egitim Teknolojisi Kuram ve Uygulama, 2(2), 42-59.

Hodges, C., Moore, S., Lockee, B., Trust, T., \& Bond, A. (2020). The difference between emergency remote teaching and online learning. Educause Review. https:/er.educause.edu/articles/2020/3/ thedifference-between-emergency-remote-teaching-and-online-learning 
Hooper, D., Coughlan, J., \& Mullen, M. R. (2008). Structural equation modelling: Guidelines for determining model fit. The Electronic Journal of Business Research Methods, 6(1), 53-60.

Hu L. T., \& Bentler P. M. (1999). Cut off criteria for fit indexes in covariance structure analysis: Conventional criteria versus new alternatives. Structural Equation Modeling: A Multidisciplinary Journal, 6(1), $1-55$.

Javaeed, A., Malik, M. N., Yaseen, M., \& Ghauri, S. K. (2020). Assessment of learning styles of undergraduate medical students and its effect on examination outcomes-a cross-sectional study done in Azad Kashmir, Pakistan. Journal of Pakistan Medical Association,

Kalaca, S. (2004). Learning styles of medical students at Marmara Medical School. (Master's dissertation). Maastricht University, Master of Health Professions Education, Faculty of Health Science, Maastricht.

Kažoka, D., \& Pilmane, M. (2019). Detailed Images for Sustainability Development in Cross-Sectional Human Anatomy. Journal of Teacher Education for Sustainability, 21(2), 27-37.

Kemahli, S., \& Alper, A. (2006). Probleme Dayali Ogrenmeye Yonelik Tutum Olcegi. Journal of Educational Sciences \& Practices, 5(10), 191-206.

Kline, T. J. B. (2005). Psychological testing, a practical approach to design and evaluation. The USA: Sage.

Kyaw, B. M., Posadzki, P., Paddock, S., Car, J., Campbell, J., \& Tudor Car, L. (2019). Effectiveness of Digital Education on Communication Skills Among Medical Students: Systematic Review and Meta-Analysis by the Digital Health Education Collaboration. Journal of medical Internet research, 21(8), e12967. https://doi.org/10.2196/12967

Lim, E. C., Ong, B. K., Wilder-Smith, E. P., \& Seet, R. C. (2006). Computer-based versus pen-and-paper testing: Students' perception. Annals-Academy of Medicine Singapore, 35(9), 599.

Marsh, H. W., Balla, J. R., \& McDonald, R. P. (1988). Goodness of fit indices in confirmatory factor analysis: The effect of sample size. Psychological Bulletin, 103(3), 391-410.

Michaelsen, V. E. (2001). The use of Web-based instruction in medical education. DEOS News, 11(5), 2-11.

Mirmoghtadaie, Z., Ahmady, S., Kohan, N., \& Rakhshani, T. (2019). Explaining the Concept and Dimensions of Professional Functions in Online Learning System of Medical Sciences: A Qualitative Content Analysis. Turkish Online Journal of Distance Education, 20(4), 61-72.

Mistry, K., Chetty, N. C., Gurung, P., \& Levell, N. J. (2019). Digital problem-based learning: An innovative and efficient method of teaching medicine. Journal of Medical Education and Curricular Development, 6 (6), 1-5.

Mubayrik, H. F. B. (2020). Exploring Adult Learners' Viewpoints and Motivation Regarding Distance Learning in Medical Education. Advances in Medical Education and Practice, 11, 139.

O’Doherty D, Dromey M, Lougheed J, Hannigan A, Last J, McGrath D. (2018). Barriers and solutions to online learning in medical education - an integrative review. BMC Med Educ, 7;18(1):130. doi: 10.1186/s12909-018-1240-0.

Ozdamar, K. (2013). Paket programlar ile istatistiksel veri analizi [Statistical data analysis with package softwares] (1st Edition). Eskisehir: Nisan.

Ozdemir, S. T. (2003). Tip egitimi ve yetiskin ogrenmesi. Uludag Universitesi Tip Fakultesi Dergisi, 29(2), $25-28$.

Pallant, J. (2016). SPSS survival manual. The USA: McGraw-Hill Education.

Rhim, H. C., \& Han, H. (2020). Teaching online: foundational concepts of online learning and practical guidelines. Korean journal of medical education, 32(3), 175-183. https://doi.org/10.3946/ kjme.2020.171

Ruiz, J. G., Mintzer, M. J., \& Leipzig, R. M. (2006). The impact of e-learning in medical education. Academic medicine, 81(3), 207-212. 
Salihu, A. S., Ibrahim, A., Owolabi, S. D., Adamou, N., Usman, U. M., Bello, M. M., \& Inuwa, I. (2020). Learning style preferences of medical students in Kano, Northwestern, Nigeria. Nigerian Journal of Basic and Clinical Sciences, 17(1), 46.

Simsek, O. F. (2007). Yapisal esitlik modellemesine giris: Temel ilkeler ve LISREL uygulamalari [An Introduction to Structural Equation Modeling: Basic Principles and LISREL applications]. Istanbul: Ekinoks.

Tabachnick, B. G., \& Fidell, L. S. (2013). Using multivariate statistics. The USA: Pearson Education.

Vieira A. L. (2011). Interactive LISREL in practice, getting started with a SIMPLIS Approach. London: Springer.

Vogelsang M, Rockenbauch K, Wrigge H, Heinke W, Hempel G. (2018). Medical Education for "Generation Z”: Everything online?! - An analysis of Internet-based media use by teachers in medicine. GMS J Med Educ, 15;35(2):Doc21. doi: 10.3205/zma001168.

Warner, R. M. (2008). Applied statistics, from bivariate through Multivariate Tecniques. The USA: SAGE Publications, Inc.

Yildirim, K. (2020). Lessons from an exceptional distance education experience. Alanyazin, 1(1), 7-15.

Yurdal, M. O. (2015) Tip fakultesi ogrencilerinin probleme dayali ogrenmeye yonelik tutumlari ile ozyonetimli ogrenmeye iliskin hazirbulunusluklari arasindaki iliski [The Relationship Between The Attitudes of Medical School Students Towards Problem-Based Learning and Their Self-Directed Learning Readiness]. (Master's dissertation). Canakkale Onsekiz Mart University Graduate School of Educational Sciences, Canakkale, Turkey. Available from the Council of Higher Education, National Dissertation Center, Dissertation ID:443527

Zhao, H., Li, G., \& Feng, W. (2018). Research on Application of Massive Open Online Course (MOOC) in Modern Medical Education Teaching. International Conference on Engineering Simulation and Intelligent Control (ESAIC) (pp. 389-391). IEEE. 